
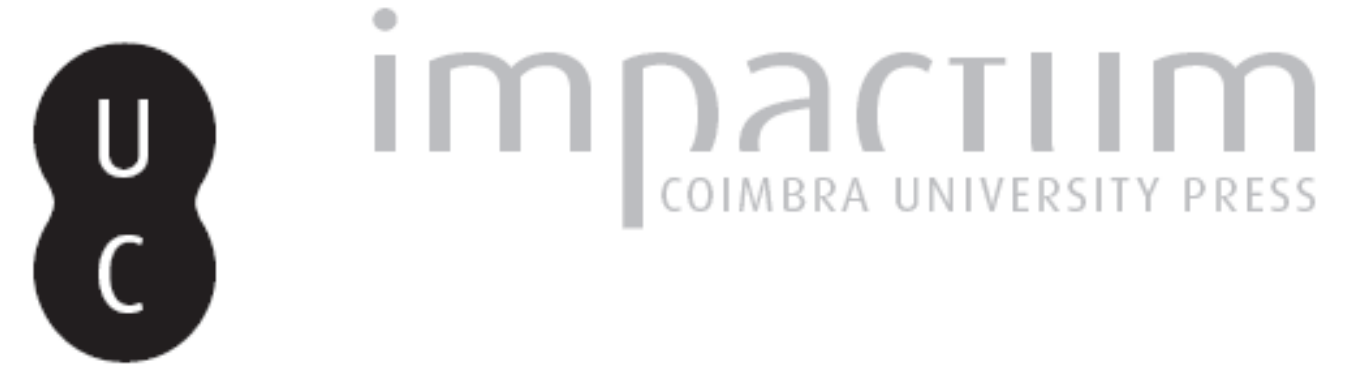

\title{
Some notes on sextus empiricus' method of approaching the téchnai
}

Autor(es): $\quad$ Brito, Rodrigo Pinto de; Arantes, Alexandre; Morais, Lauro Lane de

Publicado por: Imprensa da Universidade de Coimbra

URL persistente:

URI:http://hdl.handle.net/10316.2/42800

DOI:

DOI:https://doi.org/10.14195/1984-249X_21_8

Accessed : $\quad$ 26-Apr-2023 00:36:23

A navegação consulta e descarregamento dos títulos inseridos nas Bibliotecas Digitais UC Digitalis, UC Pombalina e UC Impactum, pressupõem a aceitação plena e sem reservas dos Termos e Condições de Uso destas Bibliotecas Digitais, disponíveis em https://digitalis.uc.pt/pt-pt/termos.

Conforme exposto nos referidos Termos e Condições de Uso, o descarregamento de títulos de acesso restrito requer uma licença válida de autorização devendo o utilizador aceder ao(s) documento(s) a partir de um endereço de IP da instituição detentora da supramencionada licença.

Ao utilizador é apenas permitido o descarregamento para uso pessoal, pelo que o emprego do(s) título(s) descarregado(s) para outro fim, designadamente comercial, carece de autorização do respetivo autor ou editor da obra.

Na medida em que todas as obras da UC Digitalis se encontram protegidas pelo Código do Direito de Autor e Direitos Conexos e demais legislação aplicável, toda a cópia, parcial ou total, deste documento, nos casos em que é legalmente admitida, deverá conter ou fazer-se acompanhar por este aviso.

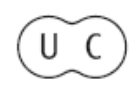




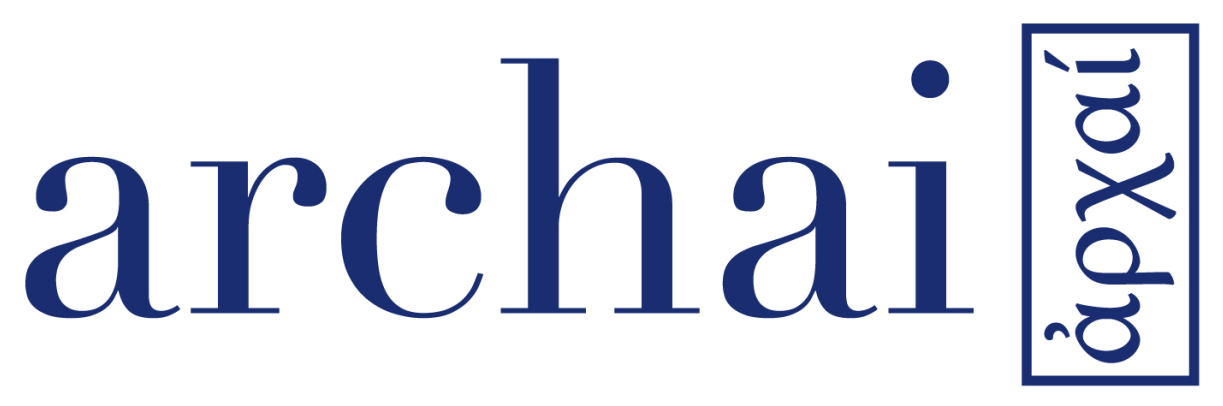

Revista sobre as origens do pensamento ocidental Journal on the Origins of Western Thought

21 | sep.-dec. 2017 
Rodrigo Pinto de Brito - Universidade Federal de Sergipe (Brasil)

rodrigobrito@gmail.com

Alexandre Arantes - PUC-Rio (Brasil)

alexandre.skvirsky@gmail.com

Lauro Lane de Morais - Universidade Federal de Sergipe (Brasil)

lauromorais@msn.com

\section{SOME NOTES ON SEXTUS EMPIRI- CUS' METHOD OF APPROACHING THE TÉCHNAI}

Pinto de Brito, R.; Skvirshy, A. A. P.; Morais, L. L (2017). Some notes on Sextus Empiricus' method of approaching the téchnai. Archai no21, sep.- dec., p. 251-279

DOI: https://doi.org/10.14195/1984-249X_21_8

\begin{abstract}
We aim to show how Sextus Empiricus develops his attack on the téchnai in Against the Professors (M I-VI). First of all, we will outline the concept of stoicheion (plural: stoicheîa) in Aristotle, for we think that the wide use of the concept by the Hellenistic Philosophers addresses itself to Aristotle's employment of it. Thus, Sextus Empiricus approaches the téchnai through a paradigm internal to their own systematization, from their "elements" (stoicheîa). Secondly, we will take into consideration Sextus' approach to grammar, and we link this discussion on grammar to the other téchnai. Finally, we aim to identify the political and pedagogical consequences of Sextus' approach.
\end{abstract}

Keywords: Pyrrhonism; Sextus Empiricus; "Against the Professors"; téchnai; stoicheîon. archai葶

no 21, sep.-dec. 2017 


\section{archai圈}

no 21, sep.-dec. 2017

Rodrigo Pinto de Brito, Alexandre Arantes Pereira Skvirsky, Lauro Lane de Morais, 'Some notes on Sextus Empiricus' method of approaching the téchnai, p. 251-279

\section{Abbreviations:}

Aristotle:

Met. $=$ Metaphysics

Rh. $=$ Rhetoric

Top. $=$ Topics

\section{Sextus Empiricus:}

$P H=$ Outlines of Pyrrhonism

$M I-V I=$ Against the Professors (or Mathematicians)

$M I=$ Against the Grammarians $=A d v$. Gram.

$M I I=$ Against the Rhetoricians $=A d v$. Rhet .

$M I I I=$ Against the Geometers $=$ Adv. Geo .

$M I V=$ Against the Arithmeticians $=$ Adv. Arith.

$M V=$ Against the Astrologers $=A d v$. Ast.

$M V I=$ Against the Musicians $=A d v . M u s$.

$M V I I-X I=$ Against the Dogmatists

$M V I I=$ Against the Logicians $I=A d v . \log . I$

$M V I I I=$ Against the Logicians II $=A d v . \log . I I$

$M I X=$ Against the Physicists $\mathrm{I}=A d v$. Phy. $I$

$M X=$ Against the Physicists II $=A d v$. Phy. II

$M X I=$ Against the Ethicists $=A d v$. Eth .

\section{Methodological PARAdigm}

This paper is not directly concerned with demonstrating the feasibility of Scepticism, regardless of how Scepticism is understood, either in its Pyrrhonian or Academic varieties. It is also not concerned with the later development and reception of the conceptual framework of Scepticism, although both subjects are going to be featured indirectly.

In this essay our goal is to think about the possible results of Sextus Empiricus' line of attack on the téchnai (arts, or crafts) as it appears mainly in his work entitled Against the Professors. In this work, the philosopher/physician methodically attacks the disciplines that form part of the cyclical studies: 
grammar, rhetoric, geometry, arithmetic, astrology and music ${ }^{1}$.

Sextus' method for destroying the téchnai is to criticize the elements (stoicheîa) which constitute these téchnai. As far as we can see from the extant evidence, Aristotle is the first to develop a philosophical conception of téchnē as a kind of craft in which the quality of the performance is related to the handling of certain constitutive elements (stoicheîa). Although in Aristotle's works the majority of the occurrences of the term stoicheîa refers to the constitutive elements of nature (cf. De Anima, 404a5; 405b8; 410a2, 17-19; 410b11; 423b28; Met.985a25, $32 ; 986 a 2,18 ; 986 b 7-9 ; 987 b 19$; etc.), there is a famous passage in the Rhetoric in which Aristotle exhorts one to discover first the various types of rhetoric in order to define them, so that one can investigate what the constitutive elements (stoicheîa) of each kind are (Rh.1358a35). Thus for Aristotle there are three kinds of rhetoric: deliberative, forensic and demonstrative. For instance, the deliberative kind is aimed to exhort or dissuade about things to do - for its special time is the future ( $R h .1358 \mathrm{~b} 14)$ - and the stoicheîa which compound this kind of rhetoric are e.g. the specific kinds of arguments used to encourage or discourage a course of action in the face of a matter which needs a deliberation, as war, so the specific arguments to be employed are always inductive ${ }^{2}$.

1 Respectively as treated by Sextus in M I-VI. The Dialectic is generally treated in $A d v$. Log.

2 Cf. Rorty (1996); Gross; Walzer (2008).

\section{archai蒡}

n 21 , sep.-dec. 2017

Rodrigo Pinto de Brito, Alexandre Arantes Pereira Skvirsky, Lauro Lane de Morais, 'Some notes on Sextus Empiricus' method of approaching the téchnai, p. 251-279 


\section{archai圈}

no 21 , sep.-dec. 2017

Rodrigo Pinto de Brito, Alexandre Arantes Pereira Skvirsky, Lauro Lane de Morais, 'Some notes on Sextus Empiricus' method of approaching the téchnai, p. 251-279
We could add more examples of Aristotelian usages of stoicheîn and stoicheîa. But let us cite only Top.120b12: "Next we must go on to examine questions relating to genus and property. These are [the] elements (stoicheîa) in the question that relate to definitions..."3; and Top.163b24:

...just as [with] geometry it is useful to be practised in the elements, and in arithmetic having the multiplication table up to ten at one's fingers' ends makes a great difference to one's knowledge of the multiples of other numbers too, likewise also in arguments it is a great advantage to be well up in regard to first principles, and to have a thorough knowledge of propositions by heart.

And we must not forget the treatment given to the letters qua elements (stoicheîa) of the syllables (Met. 993a4-10...) and qua principles (archai) of the words (Met. 998a23-25).

In short, the Aristotelian concept of stoicheîon as “... the primary immanent thing, formally indivisible into another form, of which something is composed..." (Met.1014a25) was central to the foundation and development of sciences and crafts in Hellenistic age. This enabled Sextus Empiricus to use this Aristotelian concept in order to philosophically approach the sciences and crafts and to deal with the téchnai by starting with their constitutive elements. This was something also done by other physicians of his time, as for instance Galen, who argues in his work addressed

3 All the cited passages from Topics are translated by W. A. Pickard-Cambridge, in: Barnes (1991). 
to Patrophilus that the iatriké téchnē is grounded on some elements (stoicheîa), namely health, illness, the physician (De constitutione artis medicae ad $\mathrm{Pa}$ trophilum I.247.7). But there is also a procedure or methodology of approaching the diseases by searching and trying to discover the elements (now understood as symptoms) which compound these diseases (De constitutione artis medicae ad Patrophilum I.249.2) ${ }^{4}$.

However, instead of trying to justify the crafts by starting by its constitutive elements, Sextus emphasizes that he adopts "a method of attack by approximation, and once we have overthrown its [i.e. the astrological] principles and elements, we shall find that along with them also the structure of the rest of [the astrologers'] theories has been demolished." (Adv. Ast. 49-53)

4 One could raise the question: what is the specific role of stoicheîn for Galen? Does the word have a pedagogical or a scientific role? When Galen presents the medicine to Patrophilus the word is used for displaying the most basic parts which compound and structure the science. So we can say that in De constitutione artis medicae ad Patrophilum the purpose of using stoicheîn is mainly pedagogical, but on the other hand, since Galen is displaying a science which was already structured, we can also say that he is not using stoicheîn merely by pedagogical purpose. Actually we can think that Galen is displaying it in the way he does because it is structured in this precise way.

5 All the English translations of Sextus Empiricus' quotations are by R. G. Bury, with a few modifications by us. After these quotations we will always offer the respective Greek version and our Portuguese translation in the footnotes (after //).

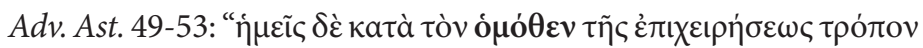

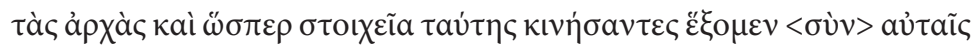

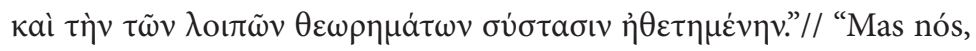
de acordo com um método de ataque por aproximação, teremos removido seus chamados princípios e elementos, e <junto > com eles [será] rejeitada a estrutura do resto de suas teorias."

\section{archai圈}

no 21 , sep.-dec. 2017

Rodrigo Pinto de Brito, Alexandre Arantes Pereira Skvirsky, Lauro Lane de Morais, 'Some notes on Sextus Empiricus' method of approaching the téchnai, p. 251-279 


\section{archai圈}

no 21, sep.-dec. 2017
Rodrigo Pinto de Brito, Alexandre Arantes Pereira Skvirsky, Lauro Lane de Morais, 'Some notes on Sextus Empiricus' method of approaching the téchnai, p. 251-279
Furthermore, according to Sextus Empiricus, "of the Sceptical philosophy one argument is called 'general', the other 'special'" $(P H \mathrm{I}, 5)^{6}$, and this drives us to a methodological paradigm similar to the one used by the physicians, for:

... just as the physicians who cure bodily ailments have remedies which differ in strength, and apply the severe ones to those whose ailments are severe and the milder to those mildly affected, - so too the Sceptic propounds arguments which differ in strength... (PH III, 280)7 .

So like Sextus would do, we are going to start by outlining how the Sceptic attacks the elements in general, and later we will turn to the art of grammar (téchnē grammatiké) in particular.

\section{The REFUtATiON TO THE ELEMENTS IN GENERAL}

The word stoicheîn has 29 occurrences in Sextus Empiricus' works, and stoicheîa (the plural of stoicheîn) has $53^{8}$. In general, in $\mathrm{PH}$ the words

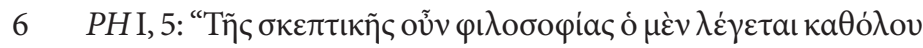

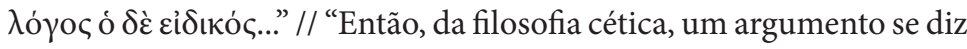
ser geral, o outro específico...”

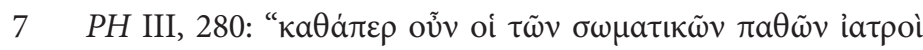

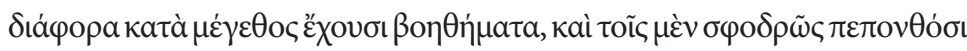

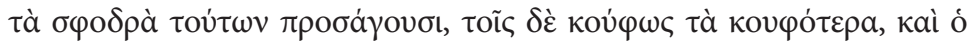

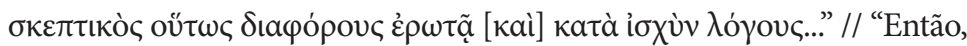
assim como os médicos têm remédios para os males corporais [que são] diferentes de acordo com a potência, e aplicam os violentos àqueles violentamente afetados, e os brandos aos brandamente, desse modo, também o cético propõe argumentos diferentes de acordo com a força..."

8 We shall emphasize that for searching and scanning the occur- 
are used to refer to physics, e.g. the atoms are the elements which compose nature $(P H \mathrm{I}, 147)$. Later, in PH II, 111, the word stoicheîa occurs four more times and it is employed in an altercation aimed at putting the atomistic physics in aporia.

In $P H$ III, 30, taking the pre-Socratic conception of $\operatorname{arché}$ (principle) as a starting point, Sextus goes against everyone who postulated material principles (hylikaí archaí) in their physics, from Pherecydes of Syros - who stated the earth as the first principle - to Pythagoras - who stated the numbers. Sextus also mentions famous "physicists", as Thales and the Milesian school, Xenophanes, Empedocles, Democritus, Aristotle and Epicurus. But he does not forget the more obscure ones: Hippasus of Metapontum, Oenopides of Chios, Hippo of Rhegium, Onomacritus, Heracleides Ponticus and Asclepiades the Bithynian9. Albeit in the steps PH III, 30-33 Sextus

rences of the words "element/elements" in Sextus' works, we selected only the plural and the singular of the nominative, vocative and accusative forms of the neuter stoicheîon, so this is not a complete scan. In a more exhaustive search (i.e. including datives, genitives in both singular and plural) someone can find at least 95 occurrences. Sure, our partial scan ignores some important occurrences, but as nominative, accusative or vocative, plural and singular, stoicheîon/stoicheîa can embrace the word as being the subject of the phrase or as being the object. So we have the opportunity to scan the word "element/elements" when Sextus employs it for saying something like: "Element(s) work(s)...”; and also for saying: "Y work (s) as element(s)", for instance.

9 PH III, 30-33: "For Pherecydes of Syros declared earth to be the first principle of all things; Thales of Miletus, water; Anaximander (his pupil), the Unlimited; Anaximenes and Diogenes of Apollonia, air; Hippasus of Metapontum, fire; Xenophanes of Colophon, earth and water; Oenopides of Chios, fire and air; Hippo of Rhegium, fire and water; Onomacritus,

\section{archai蒡}

no 21, sep.-dec. 2017

Rodrigo Pinto de Brito, Alexandre Arantes Pereira Skvirsky, Lauro Lane de Morais, 'Some notes on Sextus Empiricus' method of approaching the téchnai, p. 251-279 


\section{archai圈}

no 21, sep.-dec. 2017

Rodrigo Pinto de Brito, Alexandre Arantes Pereira Skvirsky, Lauro Lane de Morais, 'Some notes on Sextus Empiricus' method of approaching the téchnai, p. 251-279 never uses the words stoicheîn or stoicheîa, rather he mentions arché or archaí, he considers that arché and stoicheîn are both kinds of "primary immanent thing[s], formally indivisible[s] into another form,

in his Orphica, fire and water and earth; the School of Empedocles as well as the Stoics, fire, air, water and earth (...) Aristotle the Peripatetic < takes as his first principles $>$ fire, air, water, earth, and the 'revolving body'; Democritus and Epicurus, atoms; Anaxagoras of Clazomenae, homeomeries; Diodorus, surnamed Cronos, minimal and non-composite bodies; Heracleides Ponticus and Asclepiades the Bithynian, homogeneous masses; the School of Pythagoras, the numbers; the Mathematicians, the

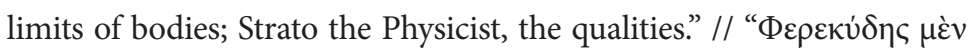

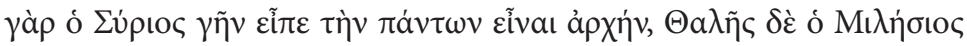

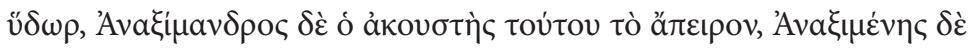

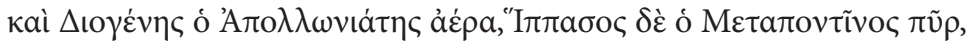

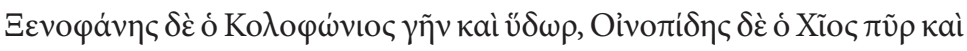

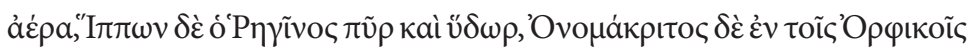

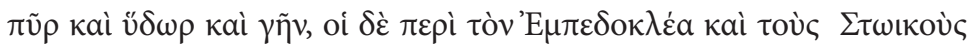

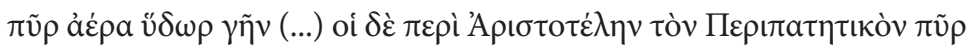

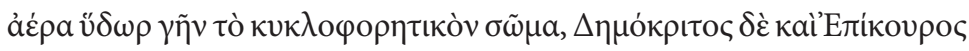

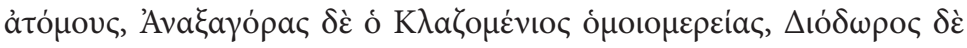

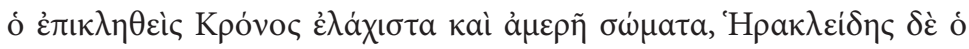

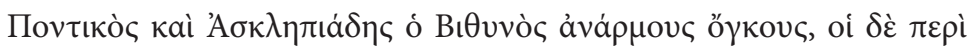

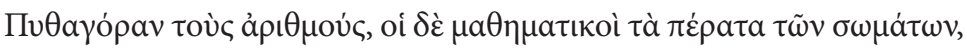

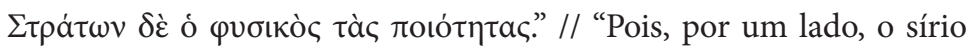
Ferecides disse ser terra o princípio de tudo; por outro lado, o milésio Tales, água; mas seu ouvinte Anaximandro, o ilimitado; Anaxímenes e o apoloniense Diógenes, ar; o metapôntico Hipaso, fogo; o colofônio Xenófanes, terra e água; o quío Oenopides, fogo e ar; o regiense Hipo, fogo e água; Onomacritos, em seu Orphica, fogo, água e terra; os em torno de Empédocles, assim como os estoicos, fogo, ar, água e terra; (...) os em torno do peripatético Aristóteles, fogo, ar, água, terra e "corpo que revolve" [i.e. o éter]; Demócrito e Epicuro, átomos; o clazomênio Anaxágoras, homeomerias; Diodoro, chamado Cronos, corpos mínimos e indivisíveis; o pôntico Heracleides e o bitínio Asclepíades, massas homogêneas; os em torno de Pitágoras, os números; os matemáticos, os limites dos corpos; Strato, o físico, as qualidades." 
of which something is composed..." as defined by Aristotle (Met.1014a25),. So it makes arché and stoicheîon share the common feature of being material principles (hylikaí archaí).

But, since there is a great divergence amongst the physicists about the real constitution of the material principles, no matter how one calls them - arché or stoicheîn - and no matter what one thinks they are - earth, water, wind, fire or atoms - the sceptic does not give assent to any of the theories, because they cannot be proved (PH III, 33-36).

And the theories cannot be proved because:

1 - If there is a proof, it must be true.

2- But for obtaining a true proof one needs a true criterion.

3- And for having a true criterion one needs first a proof that this criterion is true.

4- This proof must be true (= step 1).

So the argument is circular, and it does not allow the development of reasoning (PH III, 35). Furthermore, if there is not a proof and a criterion for judging and giving assent to material principles, it makes the material principles - both archai and stoicheîa - impossible to be apprehended, no matter what one thinks they are (PH III, 37). And it is in this train of thought that some other important occurrences of stoicheîa appear: PH III, 55.6; 62.6; 152.1,4 (with two occurrences); 153.1,4.

\section{archai圈}

no 21, sep.-dec. 2017

Rodrigo Pinto de Brito, Alexandre Arantes Pereira Skvirsky, Lauro Lane de Morais, 'Some notes on Sextus Empiricus' method of approaching the téchnai, p. 251-279 


\section{archai圈}

no 21, sep.-dec. 2017

Rodrigo Pinto de Brito, Alexandre Arantes Pereira Skvirsky, Lauro Lane de Morais, 'Some notes on Sextus Empiricus' method of approaching the téchnai, p. 251-279
But the quarrel shown above can deceive us, making us think that only physicists had theories concerning stoicheîon. And in this case we will forget that the word stoicheîn is much more overarching, since it can embrace letters - understood as elements of words - and also phrases - understood as elements of reasoning and of discourse (lógos).

So the word stoicheîa occurs in $A d v$. Log. II, 99 (or $M$ VIII, 99) ${ }^{10}$, for instance, in an argument against the assertion that the propositions become more basic while they become simpler, which makes them become in discourse similar to the elements in physics. This theory is attributed to the Dialectical School. The Sextan argumentation employed leading to aporia here has the same features of the argument against the physicists mentioned above ${ }^{11}$, i.e., the demonstration of the disagreements (diaphōniai) about what the primary elements should be, about their behavior and function, and mainly their inapprehensibility ( $A d v$. Log. II, 319.4; 336.1,3).

\section{THE REFUTATION OF THE GRAMMATICAL NOTION OF LETTERS AS SPECIFIC ELEMENTS OF WORDS}

Let us first present a few clarifying thoughts about the chronological order and sequence of Sextus' works, as this is directly relevant for an appropriate contextualization of his arguments in Against

10 We'll show in the next section (i.e. 4) why we leave the notation based in the $M$ family ( $M$ I-XI).

11 And this agenda is expanded in Adv. Phy. I, 212.6; 359.3; II, $248.8 ; 249.5 ; 253.4$ (with two occurrences of stoicheîa); 254.5 (with two occurrences); $258.3,260.2 ; 312.4$. 
the Grammarians. The usual organization of Sextus Empiricus' works divides them into three blocks: the first being composed of the Outlines of Pyrrhonism $(P H)$, subdivided into three books; the second is composed of six works organized and named as Against the Professors (or Mathematicians), usually referred to as M I to M VI (Against the Grammarians; Against the Rhetoricians; Against the Geometers; Against the Arithmeticians; Against the Astrologers; Against the Musicians); and the third is called Against the Dogmatists, usually referred to as M VII to M XI, and composed by three works (Against the Logicians, in two books; Against the Physicists, in two books; and Against the Ethicists).

But we prefer to leave this usual subdivision, since it implies that the block Against the Dogmatists would be a later work than the block Against the Professors. It appears to us that the contrary is true, i.e. the block Against the Dogmatists precedes the block Against the Professors. This assumption seems to be justified because the last book of Against the Dogmatists - Against the Ethicists, usually referred to as $M \mathrm{XI}$ - is the only book in its block which has as one of its themes the performance of the téchnai, among other things. And this performance is treated according to Sextus' methodological agenda, i.e. beginning with the most general - where philosophy appears as the art of living (téchnē perì tòn bion) (Adv. Eth. 168) - towards the most particular - where Sextus introduces the arguments which are going to be developed in the block Against the Professors, considered by us to be posterior. And the problems about the stoicheîa arise in Adv. Eth., precisely preceding and maybe introducing the

\section{archai圈}

no 21, sep.-dec. 2017

Rodrigo Pinto de Brito, Alexandre Arantes Pereira Skvirsky, Lauro Lane de Morais, 'Some notes on Sextus Empiricus' method of approaching the téchnai, p. 251-279 


\section{archai圈}

no 21 , sep.-dec. 2017
Rodrigo Pinto de Brito, Alexandre Arantes Pereira Skvirsky, Lauro Lane de Morais, 'Some notes on Sextus Empiricus' method of approaching the téchnai, p. 251-279 discussions which appear in Adv. Gram., where these "elements" (stoicheîa) are understood as elements of grammar, i.e. the letters.

Thus Sextus begins Adv. Gram. by clarifying the methodology to be employed, emphasizing that he will use some arguments that are more general and others that are more specific. So, on the one hand, for attacking the usefulness of the téchnai, general arguments are employed in order to weaken those stoicheîa which are inherent parts of the process of teaching and learning all the crafts, for example: the studies, the content to be taught, as well as the nature and function of discourse, teacher and student. These topics make up the first steps of $A d v$. Gram. On the other hand, a specific argument is one which attacks the specific elements of each téchnē.

But if the letters are the specific grammatical elements, how can the Sceptic write against the art of grammar without contradicting himself? This requires special care from Sextus, and he tells us:

And in any case even if we wished we should not be able to abolish it without upsetting ourselves; for if the arguments which show that grammatistic ${ }^{12}$ is useless are themselves useful but can neither be remembered nor passed on to posterity without it, then grammatistic is useful. Yet it might be thought by some that Timon, the expounder of Pyrrho's views, is of the contrary opinion when he says:

12 "Grammatistic" is a neologism usually employed to translate the Greek word $\gamma \rho \alpha \mu \mu \alpha \tau \iota \tau \tau$ เ the "first letters". 
"Grammar's an art that a man need neither heed nor consider

When he is still being taught the Punic symbols of Cadmus".

This, however, does not appear to be the case. For the phrase he uses, "he need neither heed nor consider," is not aimed against the actual grammatistic by which the Punic symbols of Cadmus are taught; for if a man is being taught it, how can he have paid no attention to it? What he means is rather this: "when a man has been taught the Punic symbols of Cadmus he need pay no attention to any further art of letters"; and this does not refer to the uselessness of the art which is found to deal with the elements and with employing them in writing and reading, but of that which is boastful and needlessly inquisitive. For while the handling of the elements contributes to the conduct of life, not to be contented with what is given by the observation of the elements and attempting further to show that some of them are naturally vowels, others consonants, and that of the vowels some are naturally short, others long, others doubtful and indifferently long or short, and in general all the other rules that are taught by the conceived Grammarians < are unprofitable proceedings>. $(\text { Adv. Gram. 53-55) })^{13}$.

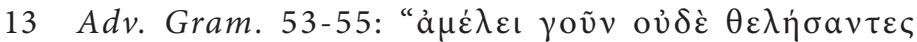

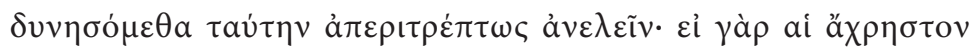

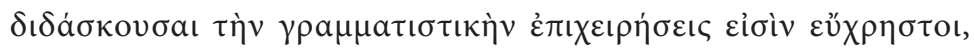

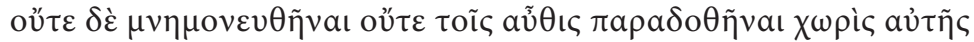

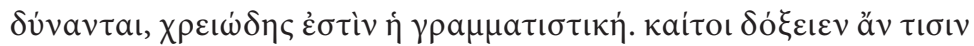

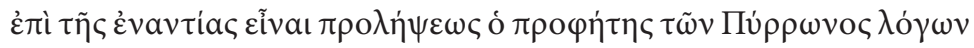

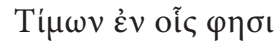

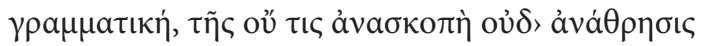

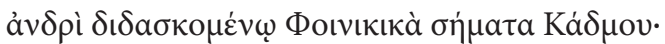

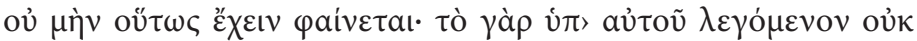

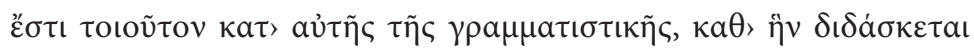

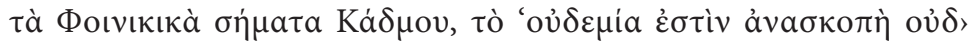

\section{archai圈}

no 21, sep.-dec. 2017

Rodrigo Pinto de Brito, Alexandre Arantes Pereira Skvirsky, Lauro Lane de Morais, 'Some notes on Sextus Empiricus' method of approaching the téchnai, p. 251-279 


\section{$\operatorname{archai}$}

no 21 , sep.-dec. 2017

\section{Rodrigo Pinto de Bri-} to, Alexandre Arantes Pereira Skvirsky, Lauro Lane de Morais, 'Some notes on Sextus Empiricus' method of approaching the téchnai, p. 251-279

\section{4}

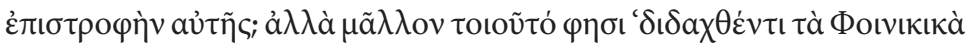

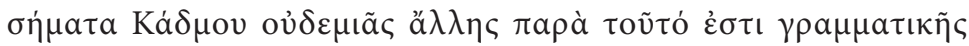

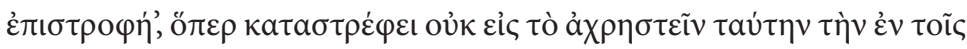

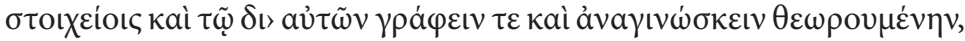

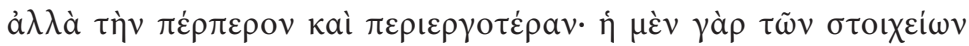

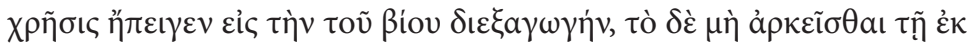

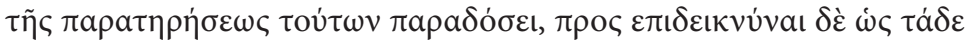

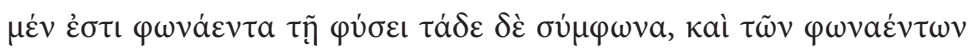

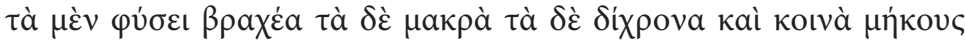

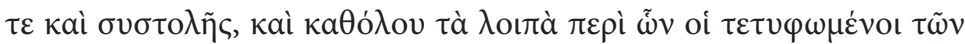

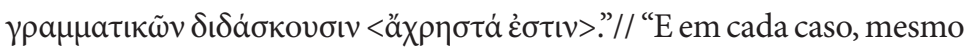
que queiramos, não podemos aboli-la sem contradizermo-nos, pois, se os argumentos que demonstram que a gramatística é inútil são eles próprios eficazes, mas não podem ser relembrados e nem transmitidos à posteridade sem ela, então a gramatística é útil. Mas talvez possa ser pensado que Timão, o expositor dos discursos de Pirro, é da opinião contrária quando diz:

Gramática, dela não há qualquer consideração nem exame

no homem que aprende os símbolos fenícios de Cadmo.

Mas esse não parece ser o caso. Pois o dito por ele "não há qualquer consideração nem exame" não é de fato dirigido contra a própria gramatística, por meio da qual se ensina os "símbolos fenícios de Cadmo", pois como [é possível], se alguém a ensina, não ter dela nenhuma consideração? Antes, o que [Timão] quer dizer é algo como: "aquele que aprendeu os símbolos fenícios de Cadmo não tem que recorrer a qualquer outra gramática além dela", o que se refere não à inutilidade desta [gramática] que lida com os elementos do alfabeto e com o emprego deles na escrita e na leitura, mas antes à presunção e desnecessidade da outra gramática. A prática com os elementos, por um lado, contribui para a conduta na vida, mas, por outro lado, não se satisfazer com o que é ensinado a partir da sua observação, e tentar mostrar, por exemplo, que alguns [dos elementos] são, por natureza, vogais, outros consoantes, e que, dentre as vogais, algumas são, por natureza, breves, outras longas, outras ambíguas e comuns em quantidade e contração, e, em geral, todas as outras coisas que são ensinadas pelos conceituados gramáticos <são [procedimentos] inúteis $>$. 
This long passage speaks for itself: Sextus knows that he would be contradicting himself if he intended to put the utility of grammar in aporia, so he divides the genus of grammar into two species: grammatistic and grammar. The first one is responsible for teaching how to deal with letters, i.e. Cadmus' Punic symbols, and it is useful and should not be despised, otherwise one would be unlettered. The second kind of grammar has its specialists - headed by the grammarians of Alexandria and Pergamum - who dedicate themselves to problems about the natural origin of utterances, sounds, etymology and the correct tones. And these grammarians are especially worried about the elements of grammar.

If the elements of grammar are the letters, we have twenty-four elements that have to compose something (the words) and which have to be indivisible into another form, they are seven vowels $(\alpha, \varepsilon, \eta, \mathrm{l}$, $o, v, \omega)$ and seventeen consonants. However there are some consonants which are double: $\zeta, \xi, \psi$; for $\zeta$ is composed by $\sigma$ and $\delta$, $\xi$ is composed by $\kappa$ and $\sigma$, $\psi$ is composed by $\pi$ and $\sigma$. But if they are double or composed by two other consonants, how can they be indivisible? In addition, if they cannot be indivisible, how can they be elements? And what about the vowels? For $\alpha, \mathrm{l}, \mathrm{v}$ have double times (they are díchrona), and as such they have a double intrinsic nature which can be expressed and proffered sometimes as long and sometimes as short, sometimes as smooth and sometimes as rough, so how can they have the oneness required for an element (Adv. Gram. 100-116)?

It briefly shows the kinds of quarrels in which the grammarians were involved, quarrels generated by

\section{archai}

nº 21, sep.-dec. 2017

Rodrigo Pinto de Brito, Alexandre Arantes Pereira Skvirsky, Lauro Lane de Morais, 'Some notes on Sextus Empiricus' method of approaching the téchnai, p. 251-279 


\section{archai圈}

no 21 , sep.-dec. 2017

Rodrigo Pinto de Brito, Alexandre Arantes Pereira Skvirsky, Lauro Lane de Morais, 'Some notes on Sextus Emproaching the téchnai', p. 251-279 piricus' method of ap-

their own peculiar projects of orthographic reform. And they also engage themselves in arguments that reveal the inutility, the vanity and the incoherence of the téchnè grammatiké.

For in a time of wide usage of the Greek language, spoken in various ways by people mostly unlettered, what would be the utility of systematizing an artificial Greek language, by creating and imposing spirits and tones for letters, genders and declinations for names, and new conjugations for verbs, if the absolute majority of people would not even know these modifications? What would be the parameter used to systematize the Hellenistic or the late-Ancient Greek, the old language of Homer? Must everyone speak as Homer did?

These are samples of questions asked by Sextus in $A d v$. Gram., but if according to Sextus an art like the rhetoric does not have an aim, the grammar on the other hand, albeit it has an aim, is not useful. According to the grammarians themselves, the aim of grammar is to give rise to a good and beautiful Greek language, or the good and beautiful usage of Greek language (hellènismós), serving as a preventive measure against solecisms and barbarisms, considered by grammarians as being linguistic mistakes. But if as we saw, the great majority of Greek speakers would not even know the grammatical parameters developed by the grammarians, it makes the purpose of systematizing the Greek language useless and vain.

Then Sextus makes the opposite argument by postulating the common use of language as the criterion for good and beautiful Greek. Thus, Sextus 
reformulates the aesthetic aspect by taking it away from the domain of the experts, and instead claims that something is called beautiful if it is in accordance with the standards of beauty engendered by the communities themselves. Moreover, Sextus emphasizes the common use of language as pragmatic criterion, since one who speaks right speaks according to linguistic conventions that are also engendered by the communities and are not creations of experts. Thus the project of the grammarians to promote themselves as the ultimate owners of criteria for the useful, good and beautiful speech is undermined by Sextus' argument.

We shall illustrate this point of Sextus pleading for a communal criterion of aesthetic beauty with the following passage of $A d v$. Mus. (29-34), as it emphasizes the theme of pleasure and it is related to the discussions proposed in general about the arts and specifically to those which appear in Adv. Gram.:

... the principal argument against music is that if it is useful it is alleged to be useful on the ground that he who has practiced music compared with ordinary people gets more pleasure from hearing musical performances; or because the elements of music are the same as those of the science of the subject-matter of philosophy, (which is much like what we previously said about grammar); or because the Universe is ordered according to harmony, as the Pythagorean fraternity declare, and we need the theorems of Music in order to understand the Whole of things; or because tunes of a certain kind affect the character of the soul. But it will not be stated that music is useful because musicians as compared with ordinary people get more pleasure from listening to performances. For, firstly, the pleasure

\section{$\operatorname{archai}$ 蔍}

no 21 , sep.-dec. 2017

Rodrigo Pinto de Brito, Alexandre Arantes Pereira Skvirsky, Lauro Lane de Morais, 'Some notes on Sextus Empiricus' method of approaching the téchnai, p. 251-279 


\section{$\operatorname{archai}$}

n² 21, sep.-dec. 2017

\section{Rodrigo Pinto de Bri-} to, Alexandre Arantes Pereira Skvirsky, Lauro Lane de Morais, 'Some notes on Sextus Empiricus' method of approaching the téchnai, p. 251-279

\section{8

felt by ordinary people is not inevitable as are those caused by food, drink and warmth after hunger, thirst and cold; and secondly, even if they are inevitable we can enjoy them without musical skill; infants, certainly, are lulled to sleep by listening to a tuneful cradle-song, and irrational animals are charmed by the sound of the flute and pipe, seeing that dolphins, as we are told, swim up to ships as they are being rowed along because of the pleasure they take in the tunes played by flutes; yet neither the infants nor the animals are likely to have skill in music or understanding of it (...) just as we enjoy tasting food or wine though without the art of cooking food or that of wine-tasting... ( $A d v$. Mus. 29-34) ${ }^{14}$.

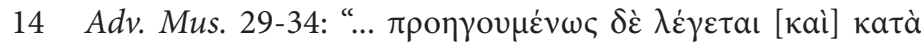

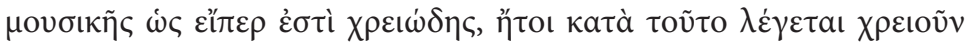

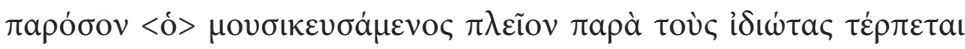

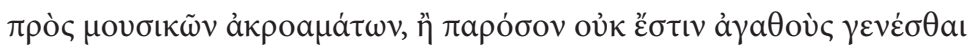

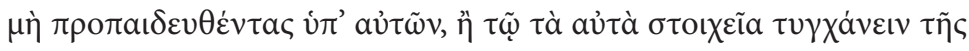

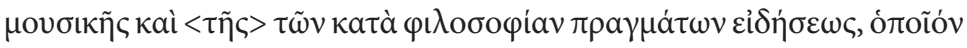

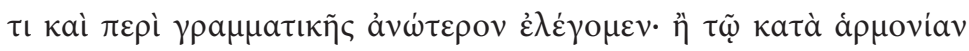

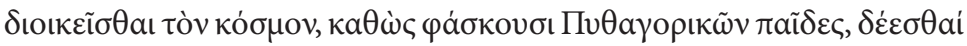

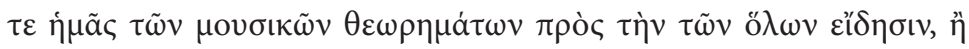

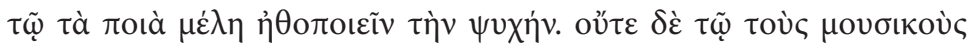

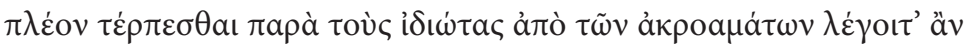

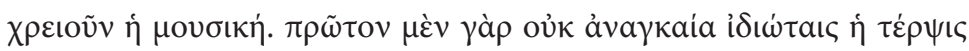

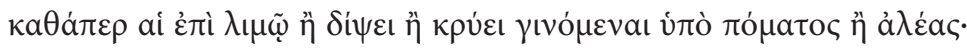

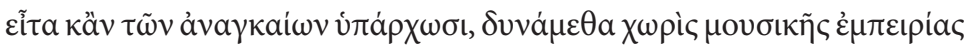

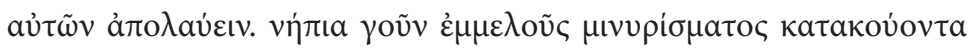

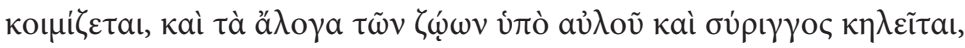

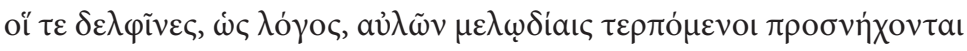

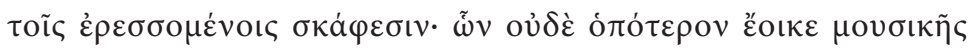

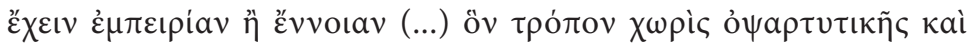

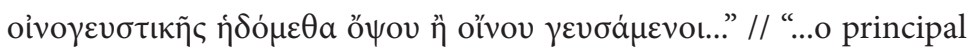
argumento contra a música é que se é útil, é pretensamente útil tendo por fundamento que, quem cultiva o gosto pela música, comparado aos ordinários, deleita-se mais ao ouvir execuções musicais, ou tendo por fundamento que é impossível os homens serem bons a não ser que 
We are now going to say a few words about the reception of Sextus' arguments against the grammarians and against their project of systematizing the Greek language through strictly theoretical paradigms, like the concept of "element".

First of all, since Sextus makes the common usage be the ultimate criterion for handling the Greek language, considering that there are lots of usages, one must have a methodology for approaching these usages. And, as we saw above, Sextus is against the theoretical approach used by grammarians, so his approach needs to be strictly based on something non-theoretical. It makes the experience (empeiría) be the methodology to be employed.

tenham sido educados através dela, ou porque os elementos subjacentes à música são as mesmas matérias cujos quais a filosofia conhece, o que é como o que dissemos anteriormente sobre a gramática, ou porque o cosmos é ordenado de acordo com a harmonia, como diziam os seguidores de Pitágoras, e precisamos dos teoremas da música para entendermos o todo das coisas, ou porque tal melodia molda o caráter da alma. Mas não terá fundamento [dizer] que a música é útil porque os músicos, comparados com os ordinários, têm mais prazer quando ouvem as execuções. Pois, primeiramente, por um lado, porque certamente esse prazer não é necessário para as pessoas comuns tal como o prazer que surge da bebida ou do calor, após a fome, a sede e o frio; mesmo que fossem necessários, poderíamos desfrutar-lhes sem habilidades musicais. Como as crianças são levadas ao sono por cantigas de ninar, e animais são encantados pelos sons da flauta e da siringe. Assim, como se diz, os golfinhos cantam para os barcos quando deles se aproximam por conta do prazer que sentem com as melodias das flautas, mas ambos [,crianças e animais,] não são especialistas em música, e nem têm a empiria e nem o entendimento. (...) assim como não se precisa ser cozinheiro ou fabricar vinhos para deleitar-se com boa comida ou bebida...”

\section{archai圈}

no 21, sep.-dec. 2017

Rodrigo Pinto de Brito, Alexandre Arantes Pereira Skvirsky, Lauro Lane de Morais, 'Some notes on Sextus Empiricus' method of approaching the téchnai, p. 251-279 


\section{archai 國}

no 21, sep.-dec. 2017

Rodrigo Pinto de Brito, Alexandre Arantes Pereira Skvirsky, Lauro Lane de Morais, 'Some notes on Sextus Empiricus' method of approaching the téchnai', p. 251-279
So we could say that the block to which $A d v$. Gram. belongs - Against the Professors - is not a strictly destructive work, even if it radically undermines any project of building theories linked to the cyclical studies. Alternatively, Sextus employs the Sceptic destructive dýnamis in order to find a new, constructive way (póros) among the aporetic discussions of the theorists and professors. But this póros is not self-evident or explicitly developed, but needs to be buildup. And it is through experience that one shall recognize this póros, as well as its limits. So the block named Against the Professors can be considered as containing a conception of knowledge which we can call empiricist and pragmatic, since it seeks the truth only by approximation and adequacy.

Turning now to the point of practicability, or the pragmatic feasibility of the Sextan Scepticism, we consider Sextus to be able to say that this praise of an empiricist model of approximated knowledge is conducted as a description, or a chronicle. He simply narrates what appears to him, and since appearances are not open to discussions, the only thing that can be discussed about them is whether they are such as the objects that generate them, or not. But the Sceptical cognition is not located in the knowledge/ world axis, around which the concepts of true and false revolve. Instead, the Sceptic ignores this axis, and appearances are all that matters to him, for appearances are coercive. So the Sceptic is not worried about the relation and adequacy of any perceptions regarding to any state of affairs.

The Sceptic is compelled by affections, and these affections cannot be refuted because they lack true 
or false value. So, if here the defense of a Sceptical empiricism is the defense of Sextus' personal experience, Sextus cannot be accused of dogmatizing, because he acts exclusively in conformity with his own experience. In the Sceptical point of view, ignoring experience in favor of an abstract truth linked to the beauty and the good would be a kind of aesthetic, epistemic, or ethical dogmatism.

Finally, this drives us back to the point of the appreciation of the personal experience, a theme which can make us think about other dimensions of the reception of Sextus' works: politics and anthropology. For in "defending" the experience of the plain human being and making it a sufficient possibility for understanding the world, the Scepticism can not only be understood as an exhortation of the phaûlos (ordinary person) against arrogant and pretentious epistemologies, but also as an admonition against the subordination and control of communities of plain people by elitist political bodies that judge themselves to be better, or by dominant power structures that treat ordinary people as vain and inferior. Furthermore, this defense of the phaûlos can become a defense of the idiótess (the private human being) in the face of hegemonic power.

But of course, reducing the scope of experience to the dimension of the strictly private and personal could be a snare here, and one could imagine that the Sceptic is a kind of radical empiricist and solipsist, who only accepts his own and peculiar impressions. And this Sceptic could (and why not?) act mistakenly during his entire life. But in order to avoid such mistakes there is a parameter for correction:

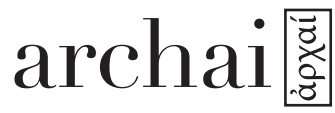

no 21, sep.-dec. 2017

Rodrigo Pinto de Brito, Alexandre Arantes Pereira Skvirsky, Lauro Lane de Morais, 'Some notes on Sextus Empiricus' method of approaching the téchnai, p. 251-279 


\section{archai圈}

no 21, sep.-dec. 2017

Rodrigo Pinto de Brito, Alexandre Arantes Pereira Skvirsky, Lauro Lane de Morais, 'Some notes on Sextus Empiricus' method of approaching the téchnai, p. 251-279

\section{2}

one should perform actions according to one's own experiences in the arena of the communal life, the arena of the habit (éthos), and of the convention or law (nomós), and also the arena of the communal (koinós), all of which the Sceptic participates in (PH I 237.7).

So Sextus' Pyrrhonian Scepticism can be interpreted as a defense of the community (koinōnía). Additionally, even when the Greek habits are compared with the habits of other peoples there are no reasons for thinking that the Greek habits are better than the barbarian ones. Thus, all the habits are considered to be of equal standing, especially if we keep in mind the tenth mode of Aenesidemus (PH I, 145-163) and the Sextan observations on the plurality of habits and conducts. So, Sextus says:

... amongst us sodomy is regarded as shameful or rather illegal, but by the Germani, they say, it is not looked on as shameful, but as a customary thing (...) having intercourse with a woman, too, in public, although deemed by us to be shameful, is not thought to be shameful by some of the Indians (...) with us tattooing is held to be shameful and degrading, but many of the Egyptians and Sarmatians tattoo their offspring... $(\mathrm{PH}$ III, 199-203) $)^{15}$

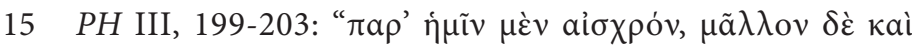

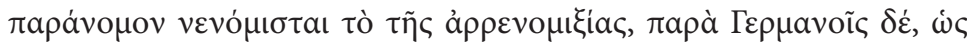

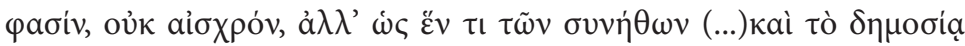

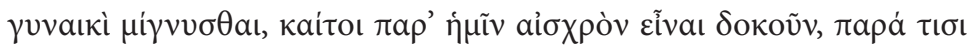

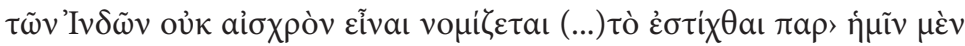

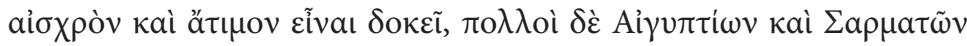

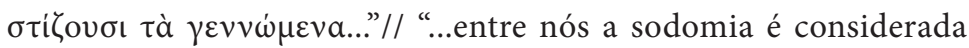
vergonhosa ou mesmo ilegal, mas entre os germânicos, dizem, é vista 
And what about the Sceptic? What does he do in the face of the plurality of habits?

Accordingly, the Sceptic, seeing so great a diversity of usages, suspends judgement as to the natural existence of anything good or bad or (in general) fit or unfit to be done, therein abstaining from the rashness of dogmatism; and he follows undogmatically the ordinary rules of life, and because of this he remains impassive in respect of matters of opinion, while in conditions that are necessitated his emotions are moderate; for thought, as a human being, he suffers emotion through his senses, yet because he does not also opine that what he suffers is evil by nature, the emotion he suffers is moderate. For the added opinion that a thing is of such a kind is worse than the actual suffering itself, just as sometimes the patients themselves bear a surgical operation, while the bystanders swoon away because of their opinion that there exists by nature something good or bad or, generally, fit or unfit to be done, is disquieted in various ways. (PH III, 235- 237) $)^{16}$.

não somente como não vergonhosa, mas mesmo como habitual (...)fazer sexo com uma mulher em público, embora seja por nós considerado vergonhoso, não é considerado vergonhoso por alguns indianos (...) para nós a tatuagem é considerada vergonhosa, mas muitos egípcios e sármatas tatuam a prole...”

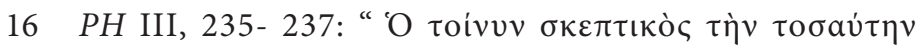

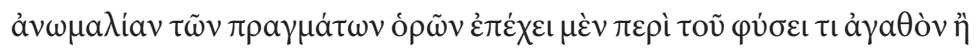

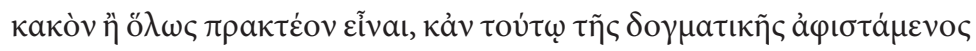

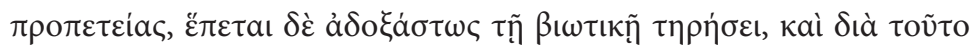

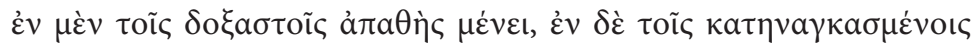

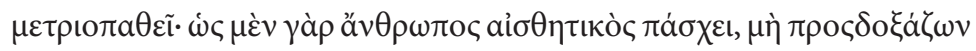

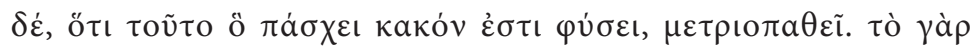

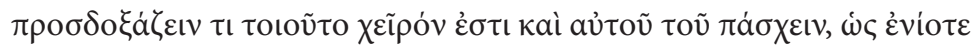

\section{archai蒡}

n'21, sep.-dec. 2017

Rodrigo Pinto de Brito, Alexandre Arantes Pereira Skvirsky, Lauro Lane de Morais, 'Some notes on Sextus Empiricus' method of approaching the téchnai, p. 251-279 


\section{archai圈}

no 21, sep.-dec. 2017
Rodrigo Pinto de Brito, Alexandre Arantes Pereira Skvirsky, Lauro Lane de Morais, 'Some notes on Sextus Empiricus' method of approaching the téchnai, p. 251-279

\section{5.- Conclusion}

As we said in the beginning of this paper, we were not directly concerned either with problems about the feasibility of Scepticism or about the reception of Sextus' arguments. We were mainly concerned with the Sextan approach to the téchnai which appears in Against the Professors, and especially with the methodology employed by him in his destructive arguments, for instance: his method of arguing first against general aspects of all issues, and arguing later against the particular aspects. And this method, once used against the concept of stoicheîon, made Sextus argue first against the own concept and later against the specific stoicheîa of grammar.

But how can someone not be worried about the practical consequences of Scepticism if against the

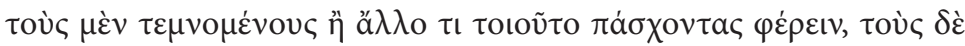

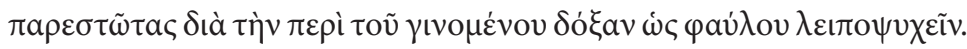

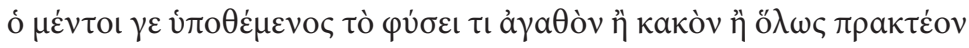

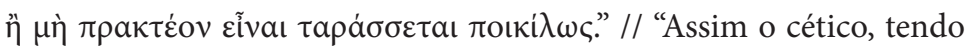
visto uma grande anomalia <acerca destas> questões, suspende o juízo sobre se algo é por natureza bom, ou mal, ou no geral praticável, aqui renunciando à precipitação do dogmático, seguindo inopinadamente a observância da vida comum, e por isso permanece impassível quanto às opiniões, mas quanto ao que é forçoso, <é> moderado; pois como homem sensível, sofre <sensações $>$, mas não $<$ tem $>$ opiniões adicionadas, como $<$ a opinião $>$ de que aquilo do que sofre é mau por natureza, $<$ portanto, é> moderado. Pois a opinião adicionada de que algo é de tal modo é pior do que o próprio sofrimento, como quando os operados ou que sofrem algo semelhante suportam $<$ bem $>$, mas os que assistem $<$ a operação $>$ desfalecem, por causa da opinião de que o que se sucede é mau. De fato, quem supõe que algo é por natureza bom, ou mal, ou no geral praticável ou impraticável, inquieta-se de vários modos.” 
grammarians Sextus employs arguments grammatically structured in Greek language? It looks like a very evident paradox, and it can be even more serious if we remember that Scepticism is often accused of inconsistence. But Sextus is not a naïve thinker, thus we tried to show that in Against the Professors he is against a conception of knowledge which is strictly theoretical. Therefore he argues against the grammarians who tried to advance theories on the structure of Greek language without paying due attention to a crucial feature of any languages: the usages.

On the other hand, Sextus' attacks do not go against the usages, and is precisely guided by these usages that he is able to write, because he handles the philosophical usage of language by not needing grammar skills (in a theoretical sense), except those learnt through grammatistic. So the Sextan Scepticism is not inconsistent if we keep in mind that the Sceptic does have a practical criterion - the local habits - and a scientific method - the empirical observation. Both the criterion and the method, once conjoined as an "empirical observation of habits", are important steps toward the development of a conception of knowledge as approximate and can be interpreted as a kind of defense of the plurality of habits.

\section{BIBLIOGRAPHY}

ANNAS, J. (1986). Doing Without Objective Values: Ancient and Modern Strategies. In: SCHOFIELD, M; STRIKER, G. (eds.). The Norms of Nature:

\section{archai蒡}

n 21 , sep.-dec. 2017

Rodrigo Pinto de Brito, Alexandre Arantes Pereira Skvirsky, Lauro Lane de Morais, 'Some notes on Sextus Empiricus' method of approaching the téchnai, p. 251-279 


\section{archai圈}

no 21, sep.-dec. 2017

Studies in Hellenistic Ethics. Cambridge, Cambridge University Press, p. 3-29.

(1996) Scepticism About Value. In: POPKIN, R. H. (ed.). Scepticism in the History of Philosophy. Amsterdam, Kluwer Academic Publishers, p. 205-218.

ANNAS, J.; BARNES, J. (eds. \& trans.) (2000). Sextus Empiricus. Outlines of Scepticism. Cambridge, Cambridge University Press.

AUSTIN, J. L. (1962). How to do Things with Words: The William James Lectures delivered at Harvard University in 1955. Oxford, Clarendon.

BAKKER, E. J (ed.) (2010). A Companion to the Ancient Greek Language. Singapore, WileyBlackwell.

BARNES, J; SCHOFIELD, M; BURNYEAT, M. Rodrigo Pinto de Brito, Alexandre Arantes Pereira Skvirsky, Lauro Lane de Morais, 'Some notes on Sextus Empiricus' method of approaching the téchnai, p. 251-279 (eds.) (1980). Doubt and Dogmatism, Studies in Hellenistic Epistemology. Oxford, Clarendon Press.

BARNES, J. (1982). The Beliefs of a Pyrrhonist. In: Proceedings of the Cambridge Philological Society, $\mathrm{n}^{\circ} 28$. Cambridge, p. 1-29. . (ed.). (1984). Aristotle. The Complete Works of Aristotle. The Revised Oxford Translation, 2 vols. Princeton, Princeton University Press.

BETT, R. (trans.) (1997). Sextus Empiricus. Against the Ethicists. Oxford, Clarendon Press.

BICCA, L. (2012). Ceticismo e relativismo. Rio de Janeiro, 7 Letras. 
BLANK, D. L. (trans.) (1998). Sextus Empiricus. Against the Grammarians. Oxford, Clarendon Press.

BRITO, R. P. de. (2013) Quadros conceituais do ceticismo anterior a Sexto Empírico. In: Prometeus - Filosofia em Revista, Ano 06, n 12, p. 121-136.

. (2014). Uma 'via média' interpretativa para o ceticismo sextiano e sua aplicação na análise de 'Contra os Retóricos'. In: Sképsis (Salvador. Online), v. 1, p. 33-69.

BRITO, R. P.; HUGUENIN, R. (trans.) (2013). Sextus Empiricus. Contra os retóricos. São Paulo, EdUNESP.

BRITO, R. P.; HUGUENIN, R. (trans.) (2015). Sextus Empiricus. Contra os gramáticos. São Paulo, EdUNESP.

BROCK, A. J. (trans.) (1991). Galen. On the natural faculties. Harvard, Harvard University Press.

BURNYEAT, M. F. (2012). Can the Sceptic Live his Scepticism? In: BURNYEAT, M. Explorations in Ancient and Modern Philosophy Vol. I. Cambridge, Cambridge University Press, p. 205-235.

. (2012). The Sceptic in His Place and Time. In: BURNYEAT, M. Explorations in Ancient and Modern Philosophy Vol. I. Cambridge, Cambridge University Press, p. 316-345.

. (2012). Explorations in Ancient and Modern Philosophy Vol. I. Cambridge, Cambridge University Press, 2012.

BURY, R. G. (trans.) (2006). Sextus Empiricus. Complete Works of, 4 vols. In: Loeb Classical Library. Harvard, Harvard University Press.

\section{archai莀}

no 21, sep.-dec. 2017

Rodrigo Pinto de Brito, Alexandre Arantes Pereira Skvirsky, Lauro Lane de Morais, 'Some notes on Sextus Empiricus' method of approaching the téchnai, p. 251-279 


\section{archai圈}

no 21, sep.-dec. 2017

Rodrigo Pinto de Brito, Alexandre Arantes Pereira Skvirsky, Lauro Lane de Morais, 'Some notes on Sextus Empiricus' method of approaching the téchnai', p. 251-279
CROWLEY, T, J. (2005). On the Use of Stoicheion in the Sense of 'Element'. In: Oxford Studies in Ancient Philosophy, XXIX , p. 367-394.

FREDE, M. (1989). The Skeptic's Beliefs. In: FREDE, M (ed.). Essays in Ancient Philosophy. Minnesota, University of Minnesota Press, p. 179-200. . (1989). The Sceptic's Two Kinds of Assent and the Question of the Possibility of Knowledge. In: FREDE, M (ed.). Essays in Ancient Philosophy. Minnesota, University of Minnesota Press, p. 201-225.

(1989). Essays in Ancient Philosophy. Minnesota, University of Minnesota Press.

GROSS, A. G.; WALZER, A. E (eds.) (2008). Rereading Aristotle's Rhetoric. Illinois, Southern Illinois University Press.

KIRK, G. S.; RAVEN, J. E.; SCHOFIELD, M (eds. \& trans.) (1994). Os filósofos pré-socráticos. Lisbon, Fundação Calouste Gulbekian.

KÜHN, C. G. (ed. \& trans.) (1821). Galen. De constitutione artis medicae ad Patrophilum. In: Claudii Galeni opera omnia, vol. 1. Leipzig, p. 224-304.

LAURSEN, J. C. (1992). The Politics of Skepticism in the Ancients, Montaigne, Hume and Kant. Leiden, E. J. Brill.

LIDELL, H. G.; SCOTT, R. (1940). A Greek-English Lexicon. revised and augmented throughout by. Sir Henry Stuart Jones. With the assistance of. Roderick McKenzie. Oxford, Clarendon Press.

MARCONDES de Souza Filho, D. (1996). Finding One's Way About: High Windows, Narrow Chimneys, 
and Open Doors. Wittgenstein's "Scepticism" and Philosophical Method. In: POPKIN, R. H. (ed.). Scepticism in the History of Philosophy. Amsterdam, Kluwer Academic Publishers, p. 167-179.

(1994). A "Felicidade" do Discurso Cético: o Problema da Auto-refutação do Ceticismo. In: $O$ Que Nos Faz Pensar, nº 8, p. 131-144.

MATES, B. (1996). The Skeptic Way: Sextus Empiricus's Outlines of Pyrrhonism. Oxford, Oxford University Press.

MOMIGLIANO, A. (1991). Os limites da helenização: a interação cultural das civilizações grega, romana, céltica, judaica e persa. Rio de Janeiro, Zahar Editores.

NUSSBAUM, M. (1991). Skeptic Purgatives: Therapeutic Arguments in Ancient Skepticism. In: Journal of History of Philosophy, volume 29, n 4, p. 521-557.

PEREIRA, O. P. (2006). Rumo ao Ceticismo. São Paulo, Editora Unesp.

PETIT, P. (1987). A civilização Helenística. São Paulo, Martins Fontes.

RORTY, A. O. (1996). Essays on Aristotle's "Rhetoric". California, University of California Press.

SMITH, Plínio Junqueira. (2007). Terapia e Vida Comum. In: Sképsis, $\mathrm{n}^{\circ}$ 1, p. 43-67.

Submitted in October (2015) and accepted for publication in February, 2016

\section{archai圈}

no 21 , sep.-dec. 2017

Rodrigo Pinto de Brito, Alexandre Arantes Pereira Skvirsky, Lauro Lane de Morais, 'Some notes on Sextus Empiricus' method of approaching the téchnai, p. 251-279 